\title{
DEVELOPING ENGINEERING WORKFORCE, DESIGNING A BETTER FUTURE
}

\author{
(Date received: 28.03.2019/Date accepted: 18.10 .2019$)$
}

\author{
Y.Bhg. Academician Tan Sri Dato’ Ir. Prof. Dr Chuah Hean Teik
}

\section{ABSTRACT}

In this paper, various trends and challenges facing the world, due to the coming of the new Digital Revolution or commonly known as the Fourth Industrial Revolution, are discussed. These include urbanisation and inequality in wealth distribution, clean air and clean water, food distribution, energy, global warming and climate change, aging population, and physicalspace and cyber-space security. To tackle the challenges, we require new ideas and inventions which will only be possible with excellent knowledge workers. New technological breakthroughs will require brand new skill sets, particularly Science, Technology, Engineering and Mathematics (STEM) skill sets, in the engineering workforce. Good engineering workforce (engineer, engineering technologist and engineering technician) is considered as the driver for the success of any nation in this globalised world. The paper also touches on the challenges faced by future engineers vis-à-vis globalisation and mobility of engineers, and what skills young engineering graduates should acquire to face the challenges. Some issues and challenges of STEM education in Malaysia are also presented. What is important now is for the educators to train future graduates who can embrace life-long learning and possess strong basic fundamentals of natural sciences and engineering, and who are ready-to-evolve rather than graduates who are just ready-to-market as many of the graduates will be entering a whole new sea of employment. Finally, the paper deals with the mobility of the engineering workforce globally and how the Institution of Engineers Malaysia (IEM) as a professional body could work with the institutions of higher learning and the Ministry of Education in the training of the required engineering workforce.

Keywords: Engineering Education, Mobility of Engineering Workforce, Skill Set for Engineering Workforce

\subsection{INTRODUCTION}

Ir. Chiam Teong Tee (fondly known as Peter Chiam), former Dean of Engineering of University of Malaya (1973-1975) and IEM Past President (1981-83), was a Mentor to the author. Both of them served in a few committees in the Institution of Engineers Malaysia (IEM) and in the IT Subcommittee of the Board of Engineers. The author had the chance to personally learn from Ir. Peter Chiam the importance of engineering professionalism and ethics. Ir. Chiam passed away in January 2016. In consideration of the immense contributions by the late Ir. Chiam to the engineering education and profession in Malaysia in general and to IEM in particular, the IEM Council decided to honour him by setting up an Annual Chiam Teong Tee Memorial Lecture.

The author had the honour to be invited by the Organising Chair, Ir. Dr Ooi Teik Aun, to be the speaker for the 3rd Chiam Teong Tee Memorial Lecture. The author presented his lecture on March 23, 2019 and this paper is a write-up on his presentation.

The paper attempts to explain the technological revolutions in human civilisation and the global trends in the Digital Revolution. Various challenges and trends in the globalised world are discussed, particularly population increase, urbanisation, energy, clean air and clean water, inequality in wealth, food distribution and environmental issues. The new Digital Revolution requires a brand new breed of engineers, technologists and technicians. As there will be many disruptive technologies, and new jobs will be created while many old jobs will become obsolete, engineering education must be reviewed.
The author proposes that engineering education should aim to train "ready-to-evolve" graduates rather than "ready-tomarket" graduates as no one can tell what jobs are going to be available and what kinds of technologies are coming in future. Thus, it is imperative to prepare the young generation with solid science, mathematics and engineering principles based on natural laws. They will need a strong foundation to be self-learners and to be able to keep abreast with the new technologies throughout their careers.

The author also presents the current scenario in engineering education in Malaysia. There is an urgent need to promote Science, Technology, Engineering and Mathematics (STEM) education among the young children even as early as primary or lower secondary school level as there is a sharp decline in the number of upper secondary school students taking Science subjects. He also proposes what professional bodies like the IEM can do to help the government, the Ministry of Education and the institutions of higher learning to train future engineers. Mobility of the engineering workforce is another important issue that the author discusses in the paper, particularly for engineering services. For mobility, it is necessary for the engineering degree programmes to be recognised regionally and globally. It is also necessary for practicing engineers to attain experience which is of substantial equivalence to their counterparts worldwide. The author also proposes 3 IC's for the engineering profession: Integrity and Competency; Integration and Communications; and Internationalisation and Cooperation. If every engineer 
carries with him/her this 3 IC's, the author is sure that the engineering profession will be highly regarded by the society and all engineers will be able to contribute to humanity as what Ir. Chiam had done.

\subsection{DIGITAL REVOLUTION AND ENGINEERING EDUCATION}

\subsection{Waves of Technological Revolution}

Over the past few centuries, human civilisation has gone through several major technological revolutions (see Figure 1), starting with the first phase of the Agricultural Revolution in the Middle Ages. One significant implement during this period was the heavy plough, which could plough deep and turn over the heavy fertile clay soils in Northern Europe. Economies and cities grew and prosperity came along. Another phase of the Agricultural Revolution came in the 1700s and it brought great changes in the way farming was done. The technological advancements via mechanisation had eased the work of farming while scientific methods allowed for the improvement of crop yields and livestock.

During the Industrial Revolution which took place in the late 18th century, the economy began to shift towards industrial and machine manufacturing. The invention of the steam engine was crucial in the Industrial Revolution. Goods were mass produced in factories, moving away from the home-based, hand-made industry. The mass production of goods led to the cheaper prices of goods. The mushrooming of factories during this period brought about drastic social, economic and environmental implications.

\section{Waves of Technological Revolution}

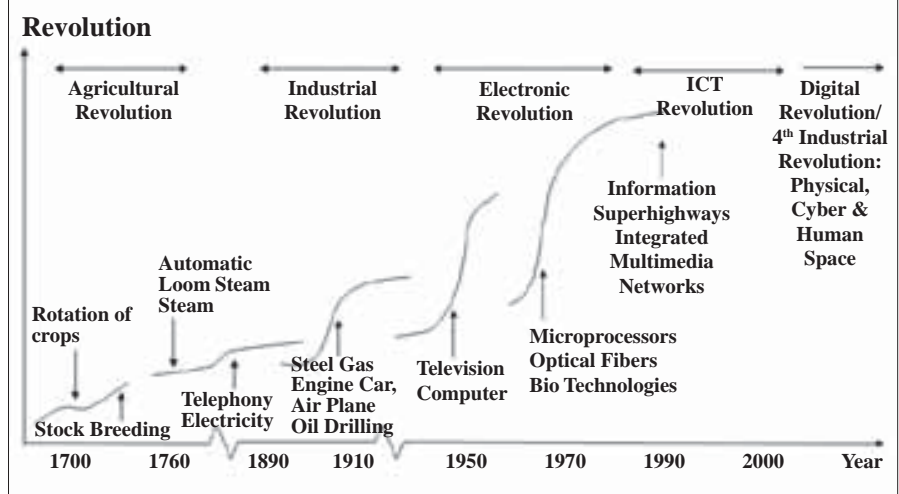

Figure 1: Waves of Technological Revolution

The Electronic Revolution, which heralded the coming of the Information Age, began in the 1950s. It marked a technological shift from analog and mechanical to digital. The invention of the transistor in 1947 paved the way for the computers and supercomputers that we use today. We began to enjoy telephones, televisions and computers. The Information and Communications Technology (ICT) Revolution, which started in the 1990s and which is still on-going, relies on the foundations built during the Electronic Revolution. It alters the way we communicate and also the way we generate, process and share information. The ICT Revolution affects almost all aspects of our daily lives, bringing profound effect to humankind.
The next wave of revolution, which is happening now as the ICT Revolution begins to spread across wider economy sectors, will see technologies being embedded in societies and even human bodies in whole new ways. Many call this the Fourth Industrial Revolution. However, the author would like to call it the Digital Revolution as it not only affects the Industry, but cuts across all sectors. Also, one should not forget about the First Revolution (The Agricultural Revolution). The Digital Revolution brings about advanced robotics and autonomous transport, artificial intelligence and machine learning, advanced materials, biotechnology and genomics. It is all set to transform our way of life and also way of work - at an exponential rate.

As we take a deeper look into the time frame of these technological revolutions, we will realise that the time span for each wave of technological revolution is becoming shorter and shorter. This means that technology is changing at a faster and faster pace. It is crucial that we should take heed of this development lest we are drowned by the technological waves.

\subsection{Widening Trends and World Challenges in the Globalised World}

We now stand at the unfolding of a technological revolution that has the immense power to affect all aspects of our lives. The changes are taking place at an unprecedented pace and no slowdown is in sight.

About 20 years ago, the pace of the already globalised world was accelerated by a new transformative creation - the Internet. Geographical borders melted away and the world evolved into a borderless global village. Due to recent advancements in transport and also technology, the effects of globalisation are even more profound. The economic event of one nation will have ripple effects in another remote nation across the globe. This presents opportunities for the initiated. As technology becomes more and more advanced, the functions of multiple electronic devices begin to converge towards a single one. For example, the radio, television and personal computer merged into a small smartphone in our hands.

Fast forward ten years, affordable mobile communication and devices put communication and the Internet into the hands of billions of people anytime, anywhere - whether for business or play. With web and mobile applications, people can get almost anything, from computers, T-shirts and phone covers to food and transport - all in a personalised manner. For example, one can order via the internet one's own designed T-shirt and it can be custom-manufactured by an AI-controlled machine and delivered to your door step within a few days. With seamless information and communication technology in hand, we have become better informed and thus, our expectations begin to grow.

As technology advances, the cost of doing everything has been greatly brought down by the increased effectiveness of processes. Technological breakthroughs and progress have basically pointed to one thing: the power of knowledge.

The world population today stands at 7 billion, and counting. By the year 2050, it is estimated that it could reach more than 9 billion. The population growth has been so rapid that it will most definitely pose serious social and economic challenges. It calls for greater efforts in meeting the basic needs for food, clean water, energy, housing, decent work, healthcare and education. 
The challenges faced by a world which plays host to more than 7 billion inhabitants are aplenty. The global wealth report published by Credit Suisse in $2017^{1}$ highlighted the widening gap between the haves and have-nots where the globe's richest $1 \%$ own half of the world's wealth.

As a whole, the global population becomes more urban. In $2010,50.5 \%$ or 3.5 billion people lived in cities. The rising level of urbanisation will reach $84 \%$ in North America and $64 \%$ in Asia. In Malaysia, it is projected that by 2050 , our population will reach 42 million and $86 \%$ of the population will be concentrated in urban areas.

With the increase in human population, human activities, which are the major contributors to the air pollution problem plaguing the world, will increase in tandem. Air pollution - the biggest environmental risk to human civilisation - causes one in nine deaths. ${ }^{2}$ Other shocking statistics on fatalities linked to air pollution include the following:

- 6.5 million people die annually due to poor air quality including 4.3 million due to household air pollution.

- 52 million years lost or lived with disability annually caused by lower respiratory infections due to household or ambient air pollution, including second-hand tobacco smoke.

- 32 million years life lost or lived each year with disability due to chronic obstructive pulmonary diseases as a result of household air pollution and workers' exposure.

- By 2030, ground level ozone pollution will reduce staple crop yields up to 26 per cent.

As the world continues to grow and progress, a lot of people are still without access to clean and safe water. ${ }^{3}$ In 2015, 2.1 billion people were without safely managed drinking water services that is, they had no access to improved water sources located on premises, available when needed, and free from contamination. Those people included:

- 1.3 billion people with basic services, meaning an improved water source located within a round trip of 30 minutes.

- 263 million people with limited services, or an improved water source requiring more than 30 minutes to collect water

- 423 million people taking water from unprotected wells and springs.

- 159 million people collecting untreated surface water from lakes, ponds, rivers and streams.

In a world where we intend to produce enough food to feed everyone, 821 million people - one in nine - still go to bed on an empty stomach each night. Even more - one in three - suffer from some form of malnutrition. ${ }^{4}$ Ironically, as people go hungry every day, around a third of the world's food is lost or thrown away each year. We waste 1.6 billion tons of food annually, worth about $\$ 1.2$ trillion dollars. ${ }^{5}$

As the earth plays host to more and more inhabitants, the big question arises, "Will the earth's resources be able to sustain this population boom?" We have already seen clear signs of the environment bearing the brunt of it. The U.S. Energy Information Administration's latest International Energy Outlook 2017 (IEO2017) projects that world energy consumption will grow by $28 \%$ between 2015 and 2040, and three-quarters of the world energy consumption through 2040 will still come from fossil fuels. ${ }^{6}$ In Malaysia, the energy consumption has increased almost three-fold from 17,728 ktoe in 1993 to 51,584 ktoe in 2013 while the energy consumption for petroleum products increased from 13,075 ktoe in 1993 to 29,190 ktoe in 2013 .
The increased consumption in fossil fuels will cause an upward trend in greenhouse gas emission resulting in the increase in global temperature. According to the Earth Policy Institute 2010 Report, from 1880 to 1970, the Global Average Temperature increased $0.03^{\circ} \mathrm{C} /$ decade. In fact since 1970 , it has increased $0.13^{\circ} \mathrm{C} /$ decade. $2 / 3$ of the increase of $0.8^{\circ} \mathrm{C}$ happened in the last 40 years. This will cause sea levels to rise and change the amount and pattern of precipitation, and we have to brace ourselves for the coming of more natural disasters. On 26 December 2004, a magnitude 9.3 temblor struck the undersea off the west coast of Sumatra creating a massive tsunami that left an estimated death toll of between 230,000 to 280,000 in 14 separate countries in its wake. In 2011, East Africa was hit with the worst drought in 60 years and in November of the same year, Thailand experienced its worst flooding in half a century.

Improvements in healthcare have vastly contributed to the increase in life expectancy. As of last year, the average life span of a Malaysian is estimated at 74.7 years; in 2000, it was 72.2 years. We have to come to terms with the fact that Malaysia is heading towards an aging nation. The United Nations Economic and Social Commission for Asia and the Pacific's 2016 population data sheet shows that in 2016, Malaysians aged 60 and above comprised $9.5 \%$ of the population. This is projected to increase to nearly a quarter of the population $(23.5 \%)$ by $2050 .{ }^{8}$ Nevertheless, does living longer means having a better quality of life? Well, not necessarily. While the rates of infectious diseases may have gone down, various National Health and Morbidity surveys show the worrying continuous upward trend of the number of those afflicted with lifestyle/non-communicable diseases such as diabetes, hypertension, obesity and cancer. ${ }^{8}$ This will add more stress to the country's healthcare system as it struggles to take care of the increasing number of aging and ill patients. Ultimately, the overall cost of healthcare will go up.

As the cyber world plays a bigger role in people's lives, cybercrimes are also on the rise. Data-destroying software, ransomware, network attacks and data thefts are becoming commonplace nowadays. Large corporations and governments are not spared from suffering massive data and consequential financial losses. E-mail and mobile phone scams have resulted in identity thefts and system frauds. Besides financial losses, there are increasing instances where cybercrimes unfold into real physical-world harms. Stalking, harassing and blackmailing, bullying, and online romance scam are some of the examples.

\subsection{The Digital Revolution (Fourth Industrial Revolution)}

The winds of change have been constantly blowing and we are now staring right into the advent of a Fourth Industrial Revolution as indicated by how technologies are emerging and impacting our lives. I would like to call it the Digital Revolution instead of the Fourth Industrial Revolution. This is to register the fact that we should not miss the First Revolution - The Agricultural Revolution. The Digital Revolution is built on previous Revolutions, particularly the Electronic and ICT Revolutions with their development of digital systems and communication, and rapid advances in computing power. In this Revolution, we will see technologies being embedded within societies and even human bodies in whole new ways. It will bring about advanced robotics and autonomous transport, artificial intelligence and 
machine learning, advanced materials, biotechnology and genomics, transforming our way of life and also way of work.

Various countries have adopted national initiatives in response to this Digital Revolution in order propel their countries ahead of looming competition as in the following chart:

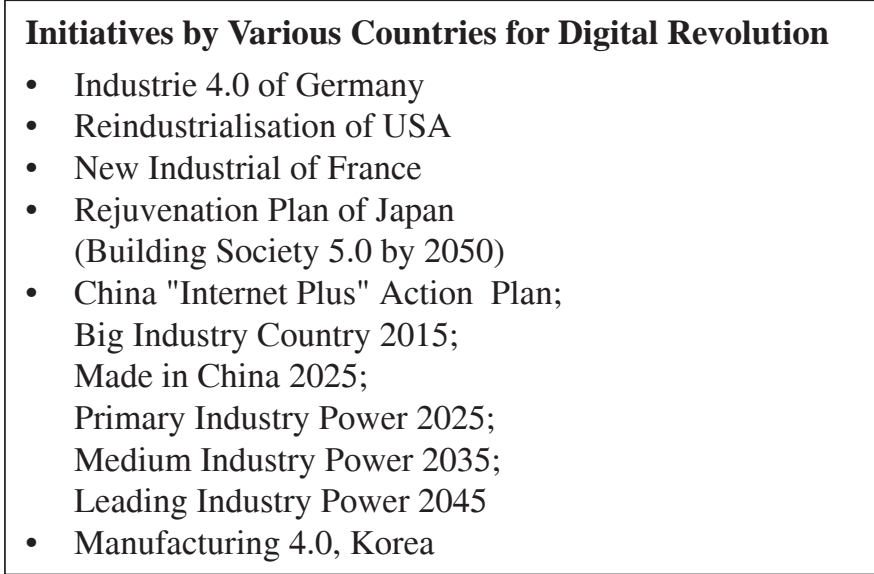

Figure 2: Initiatives by Various Countries for Digital Revolution

The Digital Revolution will affect our job or career in ways that are unprecedented. It is predicted that over one-third of the skills that are considered important in today's workforce will change. Current skills will become obsolete and new skills that are previously unheard of will leap into centre stage. "The Future of Jobs" Report published in 2016 by the World Economic Forum $^{9}$ highlighted that Digital Technologies, combined with other socio-economic and demographic changes will transform labour markets in the next five years, leading to a net loss of over 5 million jobs in 15 major developed and emerging economies. Two million new jobs will be created in the digital industrial and services sectors while 7 million jobs will be lost in traditional industrial and service sectors. It is also predicted that $65 \%$ of children entering primary school today will ultimately end up working in completely new job types that do not exist yet.

\subsection{Education - The Driver in Digital Revolution}

At the core of an innovative and productive high income economy is its human capital. Education, and thus human capital development, will need to train inquisitive and creative minds to tackle the growing global challenges and uplift the standard of living. Education can be the catalyst of change and innovation, and the driver for economic growth.

As the number of institutions of higher learning and programmes offered increase, the quality and standard of the programmes have become more critical and there is a need for some kind of quality control or assurance. Quality assurance needs to be done to ensure that the graduates produced by the institutions of higher learning are indeed competent and able to compete not only in the local scene, but also in the international arena.

Solid financing goes a long way in sustaining the well-being of the institutions of higher learning. Due to the rise of overall living costs and budget cut by government on education, there arises the pressing need to adjust the tuition fees accordingly. Nevertheless, institutions of higher learning need to strike a balance between maintaining their livelihood and avoiding higher education being exclusive to people from higher income groups. This is where new technology such as e-learning can come into play to address the rising cost of education.

Faced with constant disruption of the labour market and the fast pace of change, we need to ensure that our Technical Education is broad and diversified enough to tackle future trends. Extra focus and effort should be put into Technical and Vocational Education and Training (TVET) to prepare graduates for the real world of work. It is indeed a challenge for institutions of higher learning to tailor curricula that cater well to the demands of industries or employers in order to enhance the employability of their graduates. And it is crucial for the institutions of higher learning to continue generating fresh ideas and keep on innovating in all aspects, from programme design to delivery.

To allow students from all walks of life equal access to higher education, an understanding of the underlying concerns and the setting up of an efficient student loan/aid system have to be in place.

When all the issues surrounding higher education are properly addressed, only then will the institutions of higher learning be well poised to produce graduates who are ready to take on the task of contributing to the nation and propelling it forward.

\subsection{The U.S. Experience}

In 2005, the U.S. realised that their competitiveness in the global economy was declining in comparison to some rising Asian countries such as China, Singapore and South Korea largely due to globalisation. The U.S. National Academies were then commissioned by the U.S. Congress to study the phenomenon and to offer recommendations. The result - a report called "Rising Above the Gathering Storm: Energizing and Employing America for a Brighter Economic Future" identified the areas that are in dire need of revamps, which include the knowledge capital, human capital, and the existence of a creative ecosystem. During that period of time, the facts and statistics in higher education and research in U.S. showed a worrying trend. Financial allocations for higher education and research were significantly lower than those rising Asian countries. A huge portion of the doctoral degrees were awarded to foreign students. Also, more than a third of the workforce with $\mathrm{PhD}$ qualifications in the fields of science and technology were foreign born. Moreover, it was found that a third of U.S. students with initial intention to major in engineering ended up switching their majors before graduation. In fact, they found that the interest in science and engineering had been dwindling in the prior decade.

\subsubsection{The U.S. Experience Revisited 2010}

Five years later, the follow-up report entitled "Rising Above the Gathering Storm, Revisited: Rapidly Approaching Category 5" made even more startling discoveries. In 2009, U.S. consumers spent significantly more on potato chips than energy research and development $-\$ 7.1$ billion versus $\$ 5.1$ billion. $51 \%$ U.S. patents were awarded to non-U.S. companies. Federal funding on research in physical sciences fell by $54 \%$ in 25 years after 1970, while engineering funding declined 50\%. Even more worrying was the fact that $69 \%$ of U.S. public school students in the 5th-8th Grade were taught Mathematics by a teacher without a degree or certificate in Mathematics while $93 \%$ of U.S. public school students in the 5th-8th Grade were taught Physical 
Sciences by a teacher without a degree or certificate in Physical Sciences.

\subsection{Engineering Education in Malaysia}

An engineering personnel is a person with an analytical mind who can think logically and provide solutions based on fundamental principles of natural laws. The engineering workforce is the prime mover behind nation building. As Malaysia develops into a knowledge-based and innovation-driven economy, it is crucial that we continue to strengthen our engineering education and stimulate the growth of the engineering population. Currently, Malaysia still lags behind developed countries such as France, Germany, Canada and United Kingdom in terms of engineerpopulation ratio. It is estimated that the ratio for Malaysia now stands at about $1: 150$ and the targeted ratio by 2020 is $1: 100$.

Institutions of higher learning have to be responsive and rethink how best to train and prepare engineers to answer the challenges posed by the fast paced, competitive, global environment of the 21 st century. As a start, emphasis should be placed on strengthening the fundamentals of engineering where solutions to most complex problems can be designed.

A wholesome engineering education should also focus on nurturing engineers who have the ability to think logically and analytically and make wise decisions or propose constructive solutions based on fundamental principles of engineering. Also, engineering students should have the insatiable thirst for knowledge and the institutions of higher learning should steer them towards the path of knowledge exploration and selfdevelopment. No man is an island and engineering students would do well to have linkages to social networks that provide them the avenues for discourses and exchanges of ideas and information.

Last but not least, institutions of higher learning should provide engineering students with greater experiential preparation to work under constraints. Instead of being brought down by constraints, engineers should be inspired by them as most of the time, they may well be the building blocks that hold the key to creativity and innovation.

Admittedly, engineering education may at times be viewed in a 'not-so-positive' light. When it comes to engineering education, people always think that it is tough, boring and too technical with simply too many problems that need to be solved. And this is something that needs to be tackled and managed right from the early stages if Malaysia is to achieve its targeted engineer-population ratio.

\section{Current Scenario in Malaysia:}

1. Total Number of IHL's with Engineering Degree (Mar 2018):

- 16 Public with 195 Programmes Accredited

- 36 Private with 132 Programmes Accredited

2. Total Number of Engineering Disciplines: 27

\begin{tabular}{|l|l|}
\hline 2017 (IHL's) & $\begin{array}{l}\text { Engineering, Manufacturing and Construction } \\
\text { (\% of Overall Degree) }(\mathrm{M}: \mathrm{F})\end{array}$ \\
\hline Intake & $33409(\mathbf{1 7 . 8 \%})(\mathbf{1 : 0 . 7 0})$ \\
\hline Enrolment & $\mathbf{1 2 2 9 3 2}(\mathbf{2 0 . 3 \%})(\mathbf{1 : 0 . 6 8})$ \\
\hline Output & $\mathbf{2 7 1 4 2}(\mathbf{2 0 . 3 \%})(\mathbf{1 : 0 . 7 4 )}$ \\
\hline
\end{tabular}

Source: EAC \& Higher Education Statistics 2017, MOHE

\section{Current Scenario in Malaysia:}

Statistics of Bachelor Degree Students in Public Universities 2017

\begin{tabular}{|l|l|l|l|}
\hline & $\begin{array}{l}\text { Bachelor } \\
\text { Degree } \\
\text { (M:F) }\end{array}$ & $\begin{array}{l}\text { Science- } \\
\text { based } \\
\text { (M:F) }\end{array}$ & $\begin{array}{l}\text { Engineering, } \\
\text { Manufacturing \& } \\
\text { Construction (M:F) }\end{array}$ \\
\hline Intake & $\begin{array}{l}96483 \\
(1: 1.77)\end{array}$ & $\begin{array}{l}49027 \\
(1: 1.37)\end{array}$ & $\begin{array}{l}\mathbf{2 3 6 6 9}(24.5 \%) \\
(1: 0.88)\end{array}$ \\
\hline Enrolment & $\begin{array}{l}332023 \\
(1: 1.77)\end{array}$ & $\begin{array}{l}168873 \\
(1: 1.36)\end{array}$ & $\begin{array}{l}\mathbf{8 3 7 9 2}(25.2 \%) \\
(1: 1.36)\end{array}$ \\
\hline Output & $\mathbf{7 9 7 2 5}$ & $\begin{array}{l}39356 \\
(1: 1.51)\end{array}$ & $\begin{array}{l}19092(23.9 \%) \\
(1: 0.94)\end{array}$ \\
\hline
\end{tabular}

Source: Higher Education Statistics 2017, MOHE

Figure 4: Statistics of Degree Students in Public Universities 2017

\section{Current Scenario in Malaysia:}

Statistics of Malaysian Students in Private Institutions of Higher Learning 2017

\begin{tabular}{|l|l|l|l|}
\hline & $\begin{array}{l}\text { Total } \\
\text { (M:F) }\end{array}$ & $\begin{array}{l}\text { Degree } \\
\text { (M:F) }\end{array}$ & $\begin{array}{l}\text { Estimate of Engineering, } \\
\text { Manufacturing \& } \\
\text { Construction (\%) (M:F) }\end{array}$ \\
\hline Intake & $\begin{array}{l}\mathbf{2 2 2 3 1 5} \\
(1: 1.10)\end{array}$ & $\begin{array}{l}\mathbf{9 1 0 3 3} \\
(1: 1.09)\end{array}$ & $\begin{array}{l}\sim 9740(10.7 \%) \\
(1: 0.39)\end{array}$ \\
\hline Enrolment & $\begin{array}{l}\mathbf{5 6 5 8 5 2} \\
(1: 1.08)\end{array}$ & $\begin{array}{l}\mathbf{2 7 4 7 8 7} \\
(1: 1.06)\end{array}$ & $\begin{array}{l}\sim \mathbf{3 9 1 4 0}(14.2 \%) \\
(1: 0.39)\end{array}$ \\
\hline Output & $\begin{array}{l}\mathbf{1 4 9 8 5 7} \\
(\mathbf{1 : 1 . 2 5 )}\end{array}$ & $\begin{array}{l}\mathbf{5 4 1 2 0} \\
(1: 1.15)\end{array}$ & $\begin{array}{l}\sim \mathbf{8 0 5 0}(14.9 \%) \\
(1: 0.40)\end{array}$ \\
\hline
\end{tabular}

Source: Higher Education Statistics 2017, MOHE

Figure 5: Statistics of Malaysian Students in Private Institutions of Higher learning 2017

In March 2018, there were 52 institutions of higher learning (public and private) offering 327 accredited engineering programmes in Malaysia. However, enrolment in engineering programmes only made up about $20 \%$ of the overall enrolment in degree programmes. The ratio of male to female engineering enrolment was about 1:0.68 (see Figures 3-5).

Every year in Malaysia, about 230,000 students graduate from institutions of higher learning. Shockingly, one out of five graduates remain unemployed, with the majority being degree holders. These graduates make up $35 \%$ of those who are unemployed. The reasons boil down to the following: ${ }^{10}$

- Asking for unrealistic salary/benefits $(66 \%)$

- Choosy about the job/company (58\%)

- Poor character, attitude or personality $(58 \%)$

- Poor command of English (52\%)

- Poor communication skills (49\%)

\subsubsection{Main Challenges in Malaysia}

Efforts to increase the engineering workforce in Malaysia may well be an uphill task. For example, statistics showed that in 2014 , only about $21 \%$ of students in upper secondary schools chose to study in science subjects, and this is one of the main contributors for the shrinking engineering workforce in Malaysia. It has also been the current trend for schools leavers to rush for their degrees. This has left a great void for technicians at diploma levels.

Figure 3: IHL's with Engineering Degree 
An analysis of the Science, Technology, Engineering and Mathematics (STEM) enrolment among students in Malaysia showed a worrying trend. In 2012, a total of 441,883 students enrolled in Form $1 .{ }^{11}$ However, in 2016, only $48.6 \%$ of those students continued on in STEM streams $(23.7 \%$ in science, $8.8 \%$ in vocational and $16.1 \%$ in technical streams). It showed a leakage of 17,755 students in Form 3 and another 34,037 in Form 5. And after the Form 5 Sijil Pelajaran Malaysia (SPM) examination, in 2017 , only $19.8 \%$ of the students managed to continue on in Matriculation, Form 6 and Vocational College in STEM. This was only $8.5 \%$ of the Form 1 enrolment in year 2012 (see Figure 6)!

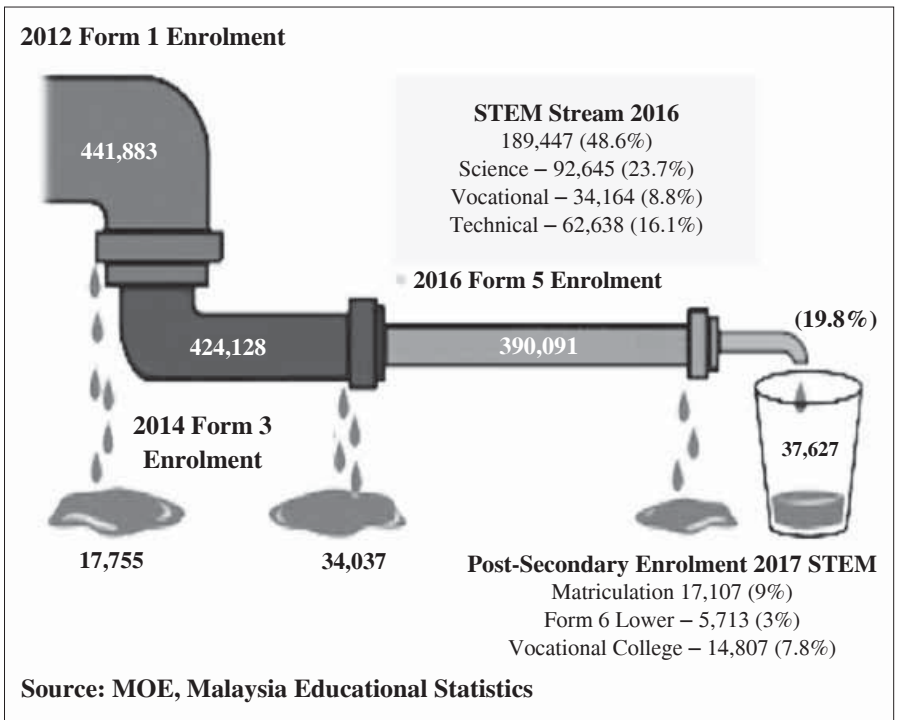

Figure 6: STEM Enrolment

The teaching profession seems to have lost its past glory and social status, and it has been quite a challenge to get qualified and experienced teachers and lecturers to teach and guide future generations of engineers. To add on to the challenges faced by engineering education, top down governance mechanism in schools and institutions of higher learning has more often than not restricts freedom for innovation.

As Malaysia moves towards a knowledge-based digital economy, its requirement for a bigger pool of highly skilled engineering workforce will naturally increase. This has led to the increased demand for higher education, and consequently, to cater to the increasing demand, the number of institutions of higher learning will also increase, leading to keen competition and the constant struggle for survival.

In this era of globalisation and internationalisation where everyone and everything become more and more interconnected and interdependent, it is imperative that institutions of higher learning take on a global approach and explore new emerging areas. Not only that, they should also strive to enhance their graduates' employability by equipping them with skills fit for this globalised world while guiding them towards building a global human network for healthy exchanges, collaboration, and support.

\subsubsection{Top Skills Required for Future Graduates}

Based on the "Future of Jobs Report", the following ten skills will take centre stage come 2020 as shown in the following chart:

\begin{tabular}{|l|} 
Top 10 Skills Required in 2020 \\
\begin{tabular}{|l|l|}
\hline$\square$ Complex Problem Solving \\
\hline$\square$ Critical Thinking \\
\hline$\square$ Creativity \\
\hline$\square$ People Management \\
\hline$\square$ Coordinating with Others \\
\hline$\square$ Emotional Intelligence \& Cultural Intelligence \\
\hline$\square$ Judgement and Decision Making \\
\hline$\square$ Service Orientation \\
\hline$\square$ Negotiation \\
\hline$\square$ Cognitive Flexibility \\
\hline \multicolumn{2}{|c|}{ Source: Future of Jobs Report, World Economic Forum } \\
\hline
\end{tabular}
\end{tabular}

Figure 7: Top 10 Skills Required in 2020

With the rapid technological changes that we are experiencing, problems and challenges will take on a more complex outlook, and solving them will require a different approach. Take for example, the designing of a dam. The engineer needs to calculate the water flow and pressure, and work on the engineering design. This is not considered complex problem solving if he/she is only looking at it from a technical aspect. However, if the engineer takes into consideration the efficiency of the dam design, the environmental impact of the dam on the natural habitat, the social economic impact and also the financial sustainability of the project, then the engineer is considered to have engaged in a complex problem solving process.

In addition to technical and professional skills, it is imperative that future graduates also master certain general skills. And social skills seem to occupy one of the prime spots. In the ten skills for future graduates listed in the "10 Trends Transformative changes in higher education" published by the British Council in June 2017 ${ }^{12}$, social intelligence is one of the top three skills that future graduates should possess. Social intelligence is all about building relationships and finding one's way around social environments. The author also thinks that cultural intelligence is going to be an important skill set. We are going to deal with different people from different countries, with different religious beliefs and cultural backgrounds. Malaysians do have an advantage due to our multi-ethic, multi-cultural, multi-lingual and multi-religious environment.

\subsection{Ready-to-Evolve Graduates - A Proposal}

The advent of the Digital Revolution has brought along a frenetic sweeping change that makes the task of predicting the future requirements of jobs almost utterly impossible. Faced with this, institutions of higher learning should realign themselves to produce graduates who are highly flexible and adept in working with new paradigms. Future graduates should be trained to be "ready-to-evolve" in line with evolving labour market requirements. As such, high priority should be given to the solid fundamental of engineering sciences such as mathematics, material sciences, electromagnetics, thermodynamics, dynamics and kinetics in the first two years of the engineering programmes. Additionally, in the first two years, while training students on the basics, more engineering application examples should be 


\section{Key Skills for Future Graduates}

\begin{tabular}{|l|}
\hline$\square$ Sense Making \\
\hline$\square$ Social Intelligence \\
\hline$\square$ Novel \& Adaptive Thinking \\
\hline$\square$ Cross-Cultural Competency \\
\hline$\square$ Computational Thinking \\
\hline$\square$ New Media Literacy \\
\hline$\square$ Trans-disciplinarity \\
\hline$\square$ Design Mindset \\
\hline$\square$ Cognitive Load Management \\
\hline$\square$ Virtual Collaboration \\
\hline Source: The Institute for the Future, British Council (2017). \\
10 Trends Transformative Changes in Higher Education \\
\hline
\end{tabular}

Figure 8: 10 Skills for Future Graduates

incorporated into lectures. As technology changes, more elective options should be introduced for students in the third and fourth years, and the Faculty should have the flexibility to review, introduce and remove these elective options as and when the need arises. At the same time, the training of skill sets should be integrated into lectures/tutorials. There is also a need for a soft skills certificate system as an added incentive for students to develop and enhance their soft skills. Additionally, students should be encouraged to participate in exchange programmes within Malaysia and internationally on a credit transfer basis to gain a broader perspective and outlook, and a deeper understanding of other cultures and global issues.

Stakeholders such as the Institution of Engineers Malaysia (IEM), the industries and the Ministry of Education Malaysia (MOE) should work hand in hand in nurturing competent and ready-to-evolve graduates. Each IEM branch could form an Advisory Committee to interact with institutions of higher learning within the State while IEM volunteers could be in the Advisory Committee of MOE to review the engineering, technologist and diploma programmes. At the same time, MOE should also work closely with IEM to promote Science, Technology, Engineering and Mathematics at the school level.

\subsection{Working with Industries and Professional Bodies}

Institutions of higher learning should forge mutually beneficial collaborations with industries and professional bodies. Being at the forefront of technology, the industries and professional bodies are in a position to provide institutions of higher learning a better understanding of the latest and future technological trends and human resource needs.

Industrial attachment in industry plays an important part in any education curriculum as it allows students to gain handson experience in applying their learnt knowledge and skills in a real working environment. It is also beneficial for the industry as the students carry fresh ideas and quality assistance with them. These students could also be valuable human assets for the industry in future. As an encouragement for closer collaboration with industries and professional bodies, academic staff members from institutions of higher learning with work or projects undertaken with industries and professional bodies should be granted sabbatical leave.
Undoubtedly, the industries and professional bodies have an integral role to play in engineering education and it will only make sense if the curriculum development takes into consideration the inputs from industries and professional bodies as after all, they are in a position to know better the knowledge and skills that an engineer should possess. Additionally, professionals in industries could share their knowledge and experience by giving guest lectures in institutions of higher learning and join forces to conduct R\&D activities for a better outcome.

Last but not least, academic staff members from institutions of higher learning could also share their knowledge and research outcomes with the industries for continual professional development of the practicing engineering personnel.

\subsection{Mobility of Engineering Workforce}

Globalisation and internationalisation through international trade, relations and treaties have set aside what once was an immobility of labour and capital between or among nations. More than ever, barriers to international trade have been considerably lowered through international agreements. This is also true for cross-border engineering works and services. According to industry analysts, demand for engineering services will grow substantially across most sectors and geographies through 2010, with only about $10 \%$ of the world's work being based in the U.S. and other developed countries, versus about $40 \%$ back in the 1990 's. So what does this entail for the engineering workforce? As the maxim goes, "With prosperity comes opportunity". For engineers, now would be the perfect opportunity to soar and spread their wings.

\subsection{Modes of Services}

The General Agreement on Trade in Services (GATS) which came into effect in January 1995 is a multilateral agreement which covers international trade in services. The GATS has created a borderless world for professionals, and engineers can take advantage of the vast opportunities offered under GATS to expand the reach of their professional services beyond their local scenes. The following are the four modes of supplying services under the GATS: ${ }^{13}$

\subsubsection{Mode 1: Cross-Border Supply}

Cross border supply covers the flows of services from one jurisdiction into any other jurisdiction. A user in economy A receives services from abroad via telecommunications or postal services. Such supplies may include market research report, telemedical advice, distance training or engineering consultancy.

\subsubsection{Mode 2: Consumption Abroad}

A consumer moves into another jurisdiction to obtain service. The consumers (Nationals of A) moved abroad as tourists, students or patients to consume the respective services in Nation $\mathrm{B}$, for example.

\subsubsection{Mode 3: Commercial presence}

The service supplier of one jurisdiction, through commercial presence, supplies services in the territory of any other jurisdiction. The service is provided by a locally established affiliate, subsidiary, or representative office of a foreign-owned and controlled company. Examples include banks, hotel groups, construction companies, etc. 


\subsubsection{Mode 4: Presence of Natural Persons}

Persons of one jurisdiction enter the territory of any other jurisdiction to supply a service. A foreign national provides a service within an economy as an independent supplier (e.g., consultant or health officer) or employee of a service provider (e.g., consultancy firm, hospital, or construction company).

\subsection{Global Mobility of Engineering Workforce}

For the development of a nation, we need many engineers - for infra and info structure development, for development of creative systems to improve human lifestyles, for proper management of natural resources, etc. The kind of engineers we require should not only excel in a particular nation, but they must also be able to stay competent and competitive regionally and globally.

We live in a borderless world brought about by regional integration, technological advancements, a free world ideology and borderless enterprises. This setup presents new opportunities and challenges to the engineering sector. To tap these opportunities, the mobility of the engineering professionals becomes crucial.

It is also important for us to develop not only regional, but also international agreements on accreditation of engineering programmes. This will be a necessary step for mutual recognition of substantial equivalence of engineering education as basic academic requirements for mobility of engineering personnel. In the 21 st century and beyond, engineering professionals need to work as a team to solve problems and improve the quality of life for humanity. This is a global effort not confined to a particular country or economy.

Consequently, within the globalisation setup, various cross-border understandings/agreements for the mobility of engineering professionals have been signed. Examples of such understandings/agreements are as follows:

- Previously known as the Engineers Mobility Forum (EMF), the International Professional Engineers Agreement (IPEA) is a multi-national agreement between engineering organisations in the member jurisdictions which creates the framework for the establishment of an international standard of competence for professional engineers, and then empowers each member organisation to establish a section of the International Professional Engineers Register.

- The APEC Engineer Agreement is an agreement in place between a number of APEC countries for the purpose of recognising "substantial equivalence" of professional competence in engineering. APEC countries can apply to become members of the agreement by demonstrating that they have in place systems which allow the competence of engineers to be assessed to the agreed international standard set by the APEC Engineer agreement.

- Formerly known as the Engineering Technologists Mobility Forum (ETMF), the International Engineering Technologist Agreement (IETA) allows for the mutual recognition of the substantial equivalency of standards establishing the competency for practicing engineering technologists.

- Agreement for International Engineering Technicians (AIET) allows for the mutual recognition of the substantial equivalency of standards establishing the competency for practicing engineering technicians.
The formal establishment of ASEAN Economic Community in December 2015 paves the way for a fully integrated ASEAN with 622 million people and a combined GDP of US\$2.6 trillion. In the regional landscape, engineering is one of the active service sectors in the ASEAN economic integration. In fact, the signing of the Mutual Recognition Arrangement (MRA) on Engineering Services in December 2005 by the ASEAN Economic Ministers reflected a shared interest between the governments and the engineering community in ASEAN to improve and enhance the competitiveness of engineering services quality as well as facilitating the free flow of engineering professionals within the region. Under the MRA, an engineering professional who is a national of an ASEAN member country and who possesses the required qualifications and experience may apply for inclusion in the ASEAN Chartered Professional Engineers Register (ACPER) and accorded the title of ASEAN Chartered Professional Engineer (ACPE). The Engineering Register set up under these various international forums and agreements is an engineer's gateway to trade liberalization in professional services.

\section{THREE IC'S - ANOTHER PROPOSAL}

In order to thrive in this fast advancing global market, engineers need to constantly keep three IC's in mind. The first IC is Integrity and Competency; the second IC is Integration and Communications; and the third IC is Internationalisation and Cooperation. ${ }^{14}$

\subsection{Integrity and Competency}

Integrity is consistency between one's action, values, methods, measures and principles. The value of a person is defined by the knowledge in the mind, the worth of the character and the principles upon which he/she builds his/her life. Handling ethical dilemmas and making ethical decisions are important parts of being a professional. Engineering is a profession that has specialised knowledge, the privilege of self-regulation, and a responsibility to the public. As engineers, it is important that we maintain a high ethical standard as the decisions we make will have a direct impact on society. It is the awareness of these heavy responsibilities and obligations that lies at the professional code of conduct and ethics that govern the engineering profession. In the practice of the profession, engineers must adhere to high principles of ethical conduct on behalf of the public, clients, employers and the profession.

Engineers must be competent to provide professional service and advice in order to protect the safety, health and welfare of the public. In such a technically complex field, new discoveries and changes in practice occur frequently. Engineers need to fully equip themselves to thrive in this competitive world. Engineers will have to be equipped with the highest standards of R\&D skills, keep abreast with global technological trends, be strategic thinkers and planners and develop market driven services and high-tech products/systems.

\subsection{Integration and Communication}

The world is becoming increasingly integrated by information systems, economic markets and political and social issues. These pose challenges that are growing in complexity and transcend specific disciplines and are driving the emergence 
of multidisciplinary and interdisciplinary thinking. Thus, it is imperative that engineers master an overwhelming array of technical knowledge.

As we move towards a more knowledge-based and innovation-driven economy, engineers too will move beyond being technically equipped, towards obtaining an even wider range of expertise, such as in research and development, consulting, regulatory knowledge, leadership, management, etc. Thus inter- and multidisciplinary approaches are becoming more prevalent in engineering.

To operate successfully in a multidisciplinary environment, it requires a broad intellectual perspective. Equally important is the ability to manipulate information into knowledge as well as understand and communicate across disciplines. Similarly, engineers are tackling multifaceted problems that require solutions beyond the reach of any single discipline. Thus, much of the work will involve teams of people from different disciplines and in some cases, from different locations around the world. It is imperative that engineers are able to collaborate and work in multidisciplinary and multicultural teams as well as communicate well in order to be effective in engineering itself.

The engineer's ability to communicate, both in writing and orally, will determine the chances of being successful as an engineer and advancing his/her career. Technical expertise alone is not sufficient if the engineer is not able to communicate useful information to colleagues, supervisors and clients.

\subsection{Internationalisation and Cooperation}

Globalisation, characterised by the increase in international trade, mobility of labour and capital, as well as borderless communication, presents new opportunities and challenges for the engineering sector. It opens up boundless opportunities in the mobility of technical expertise within the region and the global community. Engineers should aim at achieving engineering excellence not only in their home countries, but also contribute to the development of the region and the world. Local professional engineers should look beyond national boundaries and create winning partnerships with foreign professionals and high technology industry leaders abroad.

\section{CONCLUSION: WHAT WE COULD DO COLLECTIVELY}

Different stakeholders in Malaysia such as the education institutions, industries, society and policy makers have to come together and work hand in hand to strengthen engineering education in order to develop a strong engineering workforce.

For a start, institutions of higher learning should strive to gain accreditation and professional recognition for their programmes. Such accreditation and professional recognition provide those programmes with international recognition, and create benchmarks against the global standards in the respective fields. Setting standards for programmes will follow naturally as standards will serve to ensure the continuity of the accreditation and professional recognition. At the same time, they provide the necessary assurance and confidence to prospective students, graduates, employers, graduate schools, licensing agencies and government.
With the current communication technology, the ability for educators to share experiences exists on a scale never before possible. Experience and knowledge sharing is a great avenue for solving complex cross-regional problems. We should also encourage the networking of people with similar interest such as among students or educators, so that their projects and goals are more exciting and encompassing. Consequently, the energy level and success rate would be higher.

Students would not be suddenly interested in Science, Technology, Engineering and Mathematics (STEM) the day they step into institutions of higher learning. Their interest in STEM should be cultivated during their early days in school. Therefore, a fair amount of effort should be invested in going back to schools to promote STEM and to share the relevance of STEM education.

The word "engineer" brings up different impressions in different people. We should improve the image of engineers by showing more real examples of people in the engineering field, rather than leaving it to archetypes in movies and fictions. Wrong expectations may not be a good thing for motivation. People in the engineering community, be it educators, students or working professionals, should be more vocal in speaking up in order to be leaders and trend setters in their own fields. After all, they are the ones who know well where innovation can lead to.

\section{REFERENCES}

[1] https://www.theguardian.com/inequality/2017/nov/14/worldsrichest-wealth-credit-suisse

[2] https://www.unenvironment.org/explore-topics/air

[3] http://www.who.int/news-room/fact-sheets/detail/drinking-water

[4] http://www1.wfp.org/zero-hunger

[5] https://www.reuters.com/article/us-global-food-waste/ global-food-waste-could-rise-by-a-third-by-2030-studyidUSKCN1L61YR

[6] https://www.eia.gov/todayinenergy/detail.php?id=32912

[7] https://www.st.gov.my/ms/contents/publications/statistics_ energy/MALAYSIA\%20ENERGY\%20STATISTICS\%20 HANDBOOK\%202015.pdf - pages 42 \& 44)

[8] https://www.straitstimes.com/asia/se-asia/malaysia-is-ageingthe-star

[9] Future of Jobs Report 2016, World Economic Forum

[10] https://eduadvisor.my/articles/what-didnt-know-fresh-graduateunemployment-malaysia-infographic/

[11] Malaysia Educational Statistics, MOE

[12] 10 Trends: Transformative Changes in Higher Education, Institute for the Future, British Council, June 2017

[13] https://www.wto.org/english/tratop_e/serv_e/gatsqa_e.htm

[14] Presidential Address Year 2010: Engineering Mobility, Globalisation and Green Technology for a Sustainable Future, The Institution of Engineers Malaysia. 


\title{
$3^{\mathrm{RD}}$ CHIAM TEONG TEE MEMORIAL LECTURE DEVELOPING ENGINEERING WORK FORCE, DESIGNING A BETTER FUTURE
}

\author{
Presented at Tan Sri Prof. Chin Fung Kee Auditorium, Wisma IEM, Petaling Jaya, \\ Selangor Darul Ehsan, Malaysia on 23rd March 2019, by
}

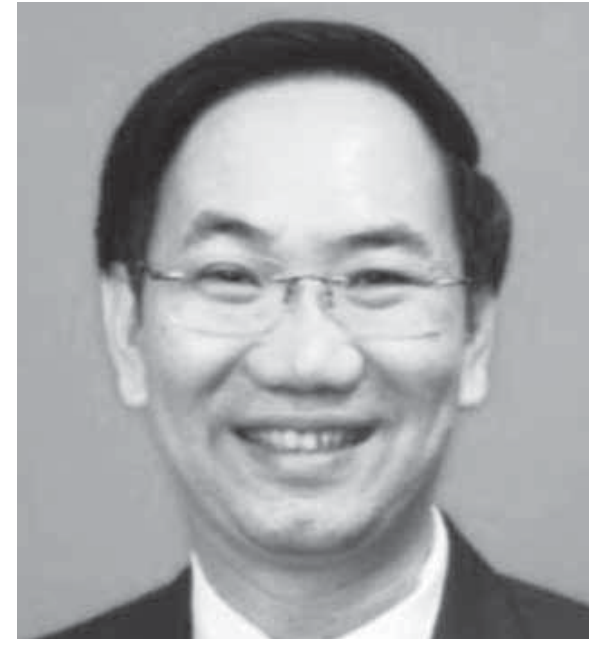

\section{Y.Bhg. Academician Tan Sri Dato' Ir. Prof. Dr Chuah Hean Teik}

Y.Bhg. Academician Dato' Ir. Prof. Dr Chuah Hean Teik, graduated with a BEng (First Class Honours), MEngSc and $\mathrm{PhD}$ in electrical engineering, all from University of Malaya, Malaysia. From July 1988-April 1997, he was on the faculty of the Electrical Engineering Department of the University of Malaya. From March-Nov 1994, he was a Fulbright Scholar at the Wave Scattering Research Centre, University of Texas at Arlington, USA. From May 1997-Jan 2008, Dr Chuah was a Senior Professor at the Multimedia University (MMU), during which he held various posts as Vice President (R\&D and Academic Development), Dean of Engineering, and Director of Research. From June 2001-Jan 2008, he also assumed the duty of the Penang State Government Professor of ICT in MMU. Since April 2008, he has been appointed as President of Universiti Tunku Abdul Rahman (UTAR) in Malaysia. He is also a Consultant Professor to Northwestern Polytechnical University, Xian, China. His research interests include microwave remote sensing and applied electromagnetics. He has authored/co-authored more than 260 papers in international journals and conferences. Dr Chuah has received many awards locally and internationally. Among them include the Professor Chin Fung Kee Gold Medal for Engineering Management in 1986, the inaugural Young Engineer Award by the Institution of Engineers, Malaysia in 1991; 1990 Young Scientist Award at the 23rd General Assembly of the International Union of Radio Science (URSI) at Prague, Czechoslovakia; 1993 Young Scientist Award at the 24th General Assembly of URSI at Kyoto, Japan; 1995 Young Scientist Award (Industrial Sector) by the Malaysian Ministry of Science, Technology and the Environment; 1999 Malaysian Toray Science Foundation Science and Technology Award for his contributions in the area of microwave remote sensing; 2002 Sterling Award from the Sterling Group of Universities (research-based universities in UK with engineering faculties) for his services to promotion of engineering profession; 2011 IET Malaysia Outstanding Achievement Award; Rotary Charity Foundation of Kuala Lumpur Research Gold Medal 2012 for excellence in original research and significant achievement in the field of electrical engineering; 2014 Distinguished Engineer Award by IEM Penang Branch, 2016 Taiwan Professional Education and Culture Medal for his contribution towards education and cultural exchange between Malaysia and Taiwan, 2017 Exemplary Leaders Award (Education Category) by The Federation of Hokkien Associations of Malaysia, and 2017 Outstanding Engineering Achievement Award by the ASEAN Federation of Engineering Organisations. In collaboration with Malaysian Centre for Remote Sensing, his research team working on "Paddy Monitoring and Yield Prediction System using Remote Sensing and GIS Technologies" won a Gold Medal at the 2003 Malaysian Science and Technology Expo, and a Gold Medal at the 32nd International Exhibition of Inventions at Geneva in 2004. In recognition of his valuable services, the Governor of the State of Penang Malaysia conferred upon him an Order of Chivalry, Darjah Setia Pangkuan Negeri, which carries the title "Dato", in July 2005. For his significant contribution in engineering profession, he was awarded Honorary Doctor of Engineering by MMU in August 2013.

Dr Chuah is an eminent technical leader. He is currently the President of the ASEAN Academy of Engineering and Technology (AAET), Past President of the Federation of Engineering Institutions of Asia and the Pacific (FEIAP) from 2011-2015, and current Chairman of FEIAP Standing Committee on Engineering Education. Dr Chuah was the President of IEM (2009-2011). He is a Senior Fellow of the Academy of Sciences, Malaysia (ASM) and AAET; Hon. 
Fellow of the ASEAN Federation of Engineering Organisations, IEM, and Myanmar Engineering Society; a Founding Fellow of The Academy of Engineering and Technology of the Developing World; Fellow of the Remote Sensing \& Photogrammetry Society, UK; the Institution of Engineering and Technology, UK; the Institute of Electrical and Electronics Engineers, USA; and the Electromagnetics Academy, USA. He is also a Professional Engineer in Malaysia, a Chartered Engineer with the Engineering Council, UK; an APEC Engineer, International Professional Engineer and ASEAN Engineer; and Hon. Member of the Golden Key International Honour Society. Dr Chuah serves as reviewer for technical papers submitted to international journals such as Progress in Electromagnetics Research (PIER) Journal, and IEEE Trans. Geoscience and Remote Sensing. He is a current member of the Disciplinary Committee Panel under the Advocates and Solicitors' Disciplinary Board, Malaysia, Council Member of ASM (2007-2011, 2014-2016), current member of Malaysian Engineering Accreditation Council (EAC) and was a Council Member of the Malaysian Qualifications Agency (20082012). He also serves in Technical Committee or Advisory Committee of a few regional and international conferences and symposia.
Due to his technical expertise, he has been appointed to various committees at national level, which included:

1. Member, Civil Aviation Authority of Malaysia, Ministry of Transport (2018-2021).

2. Chairman, klia2 Independent Safety Committee (appointed by Minister of Transport Malaysia in Dec 2014) to review safety issues for KLIA2 Airport in Malaysia (2014-2015).

3. Member, Malaysia Education System Review Panel, appointed by Government of Malaysia as one of the 12-member Panel to review the Education Blueprint of Malaysia (2012).

4. Member of Selection Committee for Science and Technology Award and Science and Technology Research Grant, Malaysia Toray Science Foundation (2012-to-date).

5. Member, Auditor Committee, Mahathir Science Award Foundation (2012-to-date).

6. Member of Examination Committee for Science Education Award of Malaysia Toray Science Foundation (2006-2011).

7. Member of the Independent Investigation Panel, Cabinet of Malaysia Government, for the Cameron Highlands Bus Accident (2011). 